\section{THE ADMINISTRATION OF CHLOROFORM.}

\section{To the Editors of THE LANCET.}

Sirs,-In your number for $J$ une 13 th a case of death fol. lowing the administration of chloroform is published by Dr. Thomas A. Dodd, Newcastle-on-Tyne. Toe case is a suggestive one, pointing as it does in such very clear terms to the conclusions of the Hyderabad Commission. There is here the early effect of chloroform narcosis on the respiratory centre, "his breathing suddenly stopped," and after recourse to artificial respiration the re establishment of the respiratory function. The death subsequently, "evidently from cardiac syncope, having never regained consciousness," shows how closely the case was watched. It bas always appeared to me that in the controversy raised since the issue of the Hyderabad Commissioners' report, the two sides assumed by the opposing controversialists have to a large extent been due to misunderstanding. For myself, I think the position taken up by the Commissioners is the one that will in the end prove to be correct. One of the main conclusions arrived at by the Commissioners after the postulate, that deaths following chloroform administration occur from failure of the respirat on, is this, that chloroform canses great fall in the blood pressure. Is not this sufficient to account for the pallor and the loss of pulse at the wrist, quite enough to suggest cardiac syncope until some other cause could be assigned for these phenomena? It appears to me that this conclusion will be irresistible, and one cannot but hope that it will be reached without mixing personal matters in what is, after all, a purely scientific inquiry. In the case under consideration one hour and a quarter elapsed before death took place; the patient breathed again regularly, but did not regain conscionsness. This result seems to be accounted for only on the hypothesis of lowered blood pressure reacting on what were doubtless already weakened vital powers, the central nervous system being starved for want of blood. The only other question to discuss here seems the treatment. If the blood pressure is lowered by the chloroform, is alcohol indicated? Would not the sub. cutaneous injection of digitaline be more rational ? I have not experienced the loss of a patient under chloroform. Four cases of threatened complications have occurred to me; in each case failure of the respiration has been the first indication of danger; all revived and got over the crisis. I enclose my card, and am, Sirs, yours truly, June 10th, 1891.

INQUIRER.

\section{To the Editors of THE LANCET.}

$\mathrm{SIRS}_{3}-\mathrm{A}$ case is reported in your issue of June $13 \mathrm{th}$ of a recent death from chloroform at Newcastle-nn-Tyne, from which I think a useful practical lesson may be learnt. As you say, the operation was one of necessity, and both it and the administration of the anasthetic appear to have been carried out carefully and skilfully ; but I think, in all fairness, a criticism may justly be made, and that is, with regard to the anæsthetic eniployed. I think, in spite of the conclusions arrived at by the Hyderabad Chloroform Commission, that there must be many who believe as I do, after $t w n$ years almost daily administration of anæsthetics, that chloroform does exercise a depressant effect upon the heart centre in the medulla oblongata, as it also undoubtedly depresses the respiratory centre; in fact, it seems hardly possible that a powerful agent of the nature of chloroform can affect the respiratory centre so power. fully without also affecting in some degree and in like manner the cardiac centre, which lies so close to it. Had ether been the anjesthetic employed in the case under consideration, one cannot help thinking the unhappy calamity would probably have been avoided. Ether, we know, stimulates the hearc's action, and I believe it also stimuIates the respiratory system. Now, when there is so large a quantity of pus in the pleura as a quart, compressing the lung and most serionsly interfering with the circulation of blood through the lung and embarrassing the heart's action, must it not be in the highest degree dangerous, and rather nnfair to our patient, to administer an anæsthetic which may even possibly depress the heart still more when we have at hand an anæsthetic like ether, which we know stimulates the circulation. Another point in the case which is most interesting is that when the patient' $*$ breathing bad stopper artificial respiration was done, and all seemed well until the chest was opened and a quart of pus evacuated, when the pulse was noticed to be failing. The reason of this I take to be that as it was a tolerably recent empyema, and the lung was probably not much bound down, on the withdrawal of the fluid there was a sudden expansion and rush of blood to the lung. 'This sudden detraction of blood from the heart and brain caused the failure of the heart's action, from which, in the opinion of the medical attendants, the patient died. The case shows clearly that there was first failure of respiration, which was recovered from, and then failure of the heart, from which death took place. The lesson to be learnt is that ether should be the anæsthetic always employed when operations are performed for the removal of large quantities of fluid from the pleura, unless there is any special circumstance in the case which contraindicates its use, and that we can by no means disregard the heart, or never bother our heads about the pulse when giving chloroform, as a recent correspondent in THE LANCET suggests we may do.-I am, Sirs, yours faithfully, June 15th, 1891. House SURGEON.

\section{ALCOHOL AND LONGEVITY.}

\section{To the Editors of THE LANCET.}

SIRS, - The annual report of the Urited Kingdom Temperance and General Provident Institution, in which the expected and actual claims for the year 1890 are given, affords another opportunity of testing the comparative longevity and vitality of total abstainers and drinkers of alcoholic liquors. The weight and conclusiveness of this test increase with every year. The twenty-fifth return is as follows:

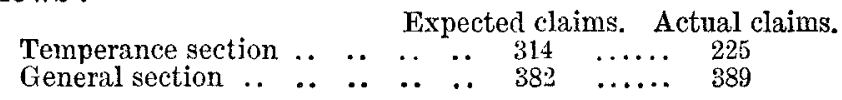

This shows 71.6 per cent. in the temperance section and 100.2 per cent. in the general, a difference of 28.6 per cent. in favour of the abstainers. This is a little higher than the averages of the whole twenty. five years, which are 69.9 and 96.6 per cent. respectively, a difference of 26.7 per cent. The advantage of total abstinence is shown by the following five quinquennial returns:

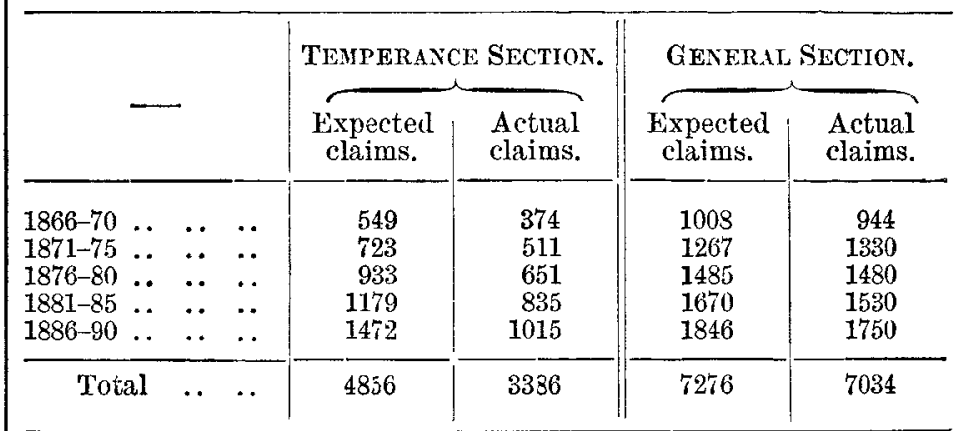

This table shows that while in the general section the deaths have fallen short of the expected number by 242 , in the temperance section the deaths are 1470 fewer. The fact that in the general section the deaths are below the healthy male average proves conclusively that the difference between the two sections is not due to excessive drinking on the part of any considerable number of the general section. The comparison, therefore, is fairly between abstainers and moderate drinkers-rather more moderate than the average middle-class picked lives, - and shows conclusively that the use of alcoholic liquors produces degeneration of the tissues and shortens life.-I am, Sirs, yours truly, J. J. RimgE, M. D. Lond.,

Enfield, June 8th, 1891 Hon. Sec. British Medical Temperance Association.

\section{THE GENERAL MEDICAL COUNCIL AND INCREASED REPRESENTATION.}

\section{To the Editors of THE LANCET.}

SIRS,-It is to be hoped that this suggestion of Dr. Rentoul with regard to increasing the number of the members of the General Medical Council will not be carried out by the Privy Council. It is difficult enough now for the work to be accomplished in each session owing to the number of "voices" which require to be heard on each subject which arises for discussion. Instead of adding to their number, it would be almost worth considering by the Privy Council whether grouping of smaller corporate bodies, such as the Apothecaries' Companies in England and Ireland, and the various faculties of physicians and urgeons, and 
giving each group a representative, would not be greatly to the advantage of the profession generally, and the Council in particular. Whilst the present system obtains it would be adding to the difficulties already met with by increasing the number of even the direct representatives. Large committees are notoriously unmanageable, and great loss of time results from the fact that each member of the Council has to "do something" for the "constituency" he represents. I should imagine that the funds of the Council would also seriously suffer by such an addition to the current payment of new members. The present directrepresentatives have done their duty most excellently, and the interests of the profession at large can safely be lett in their hands; remembering as we ought that although the other members of the Council are not directly elected by the profession, yet it would be almost, if not entirely, impossible for us to find better representatives were the election in our own hands. If any alteration is required in the Council it is a lessening in its numbers, not an addition, and this lessening can best be gained by the grouping I have suggested above. I wenture to hope that medical men will think, not twice, but many times, before signing the petition to the Privy Council.

I remain, yours faithfully,

$$
\text { A. George Bateman. }
$$

Constitutional Club, S.W., June 20th, 1891.

\section{EUCALYPTUS OIL IN THE TREATMENT OF SCARLET FEVER.}

\section{To the Editors of THE LANCET.}

SIRS, - As being the first person to bring before the notice of the profession the method of treatment of scarlet fever by inunetion of eucalyptus oil in combination with other essential oils and camphors, allow me to point out to $\mathrm{Dr}$. Knox Bond that his treatment of scarlet fever by encalyptus oil was not after the method recommended by rne in a paper to be found in the Transactions of the Epidemiological Society, and which has been republished by Lewis in a separate form. I am not astonished that his trial failed, and could have told him that it would if he had communi cated with me. I and my son and many medical men have during the last two years treated all scarlet fever cases by inunction of Tucker's Eucalyptus Disinfectant with uniform success, shortening the duration of the fever, enabling the patients to mix with the rest of the family after ten days, requiring no isolation, and preventing all serious sequelæ. He will see in my paper that I condemn all greasy prepara. tions for inunction, but the essential oils and camphors composing the disinfectant are all highly volatile, and are in no way greasy. I should like also to inform him that most of the eucalyptus oil of commerce does not possess the antiseptic qualities that are absolutely necessary for its successful use in infectious diseases. I have for some years tested experimentally the different eucalyptus oils, as well as other essential cils, and hope one day to make known the results of $\mathrm{my}$ inquiries, for there are some of these oils that are more powerful antiseptics and germicides than the oil of eucalyptus globulus.

June 11th, 1891.

I am, Sirs, yours obediently,

$$
\text { J. BRENDON CURGENVEN. }
$$

\section{LIVERPOOL. \\ (From oUr OWN CoRrespondent.)}

The Census Returns of Liverpool.

THE census returns of this city showing a considerable falling off in the population since 1881 has surprised many persons, being the very reverse of what they had expected, and yet on reflection there were several reasons why this reduction should not surprise us. Whole streets of houses have been demolished and their sites remain howling wildernesses, no other houses having been built to replace them. This is a defect which it is to be hoped the authorities will soon rectify. Much has been done for the working man; but in Liverpool, as elsewhere, he wants, and mustalways want, a home near his work, where, for the same rent which he formerly paid for a wretched insanitary dwelling, he can have a real home with every means for himself and his family to live in decency.
Liverpool and the Cheshire Side.

There is another fact which may account for the alleged reduction in the population of Liverpool. The Mersey Tunnel Railway has been extremely popular, and has brought Liverpool and New Brighton within twenty minutes' journey by any ordinary train, some doing the journey in a quarter of an hour. In other words, persons can leave the overcrowded city and be in a charming seaside resort, with a totally different climate, in half an hour. There are also Hoylake, West Kirkby, Egremont, Seacombe, Rock Ferry, and Bebington, all on the Cheshire side, with residences to suit all classes. It would be quite contrary to reason were advantage not taken of these opportunities of sleeping out of the crowded city, and the probabilities are that Liverpool will grow westward on the Cheshire side, the growth north, south, and east having almost reached its extreme limit.

$$
\text { The Weather and the Influenza. }
$$

Although the weather is now intensely hot, cases of the so.called influenza still occur and assume a very severe type. Members of the profession have suffered more or less severely, while some have escaped.

\section{The Magistrates and the Temperance Advocates.}

The meeting of the city magistrates to-day was attended by a deputation of citizens, who came in such large numbers as to fill all the vacant space of the somewhat large room. The deputation comprised clergy, doctors, and laymen, who urged upon the magistrates the importance of reducing the number of public-houses. Dr. Carter described the shocking sights seen in Liverpool hospitals on a Saturday night, and all agreed in urging the magistrates to encourage temperance and to discourage intemperance. Unfortunately, Liverpool is suffering to-day from the actions of magistrates of a bygone age, who, fearing to encourage a monopoly in drink, granted licences to every applicant, the result being a jump from the frying-pan of monopoly into the fire of a legion of public-houses. The question is a very difficult one; but in the face of recent legal decisions there seems no reason why new applicants hould not be refused if more public-houses are not required.

Liverpool, June 24th.

\section{NORTHERN COUNTIES NOTES.}

\section{(FROM OUR OWN CORRESPONDENT.)}

\section{The Gynocological Congress at Neucastle.}

The Gynæcological Congress at Newcastle last week was very successful. As a meeting the attendance was good, and the interest of the papers and discussions was well sustained. At the banquet at the Assembly Rooms the honorary president, De. R. Barnes, presided. Dr. Oliver, in speaking to the toast of "The British Gynæcological Society," said that the success of the Society's gathering on that occasion was to be attributed to the activity of $\mathrm{Dr}$. Benington, the local secretary, and to Dr. Murphy, of Sunder]and. The President, Dr. Grigg, thanked the profes. sion in the north for the reception accorded them, and alluded to the splendid accommodation afforded by the Durham College of Medicine, which, as a building, far exceeded most of the London schools. On Saturday the gynacolngists broke away into the country, making an excursion to the Roman Camp and other objects of interest on the North Tyne, and finally made " a raid" (by arrangement) on Swinburn Castle, where they were received by Dr. Wm. Murray with his usual hospitality.

$$
\text { Consett Public Park. }
$$

It is arranged that the handsome public park granted to and laid out for the district by the Consett Iron Company will be ready for opening by July $11 \mathrm{th}$, and a demonstration will take place by the friendly societies, trades unions, and other public bodies of the district.

\section{Durham.}

Mr. J. J. Robinson, a littérateur and formerly editor of the Durham Chronicle, has been appointed editor and manager of the West Sussex Gazette. Mr. Robinson was highly respected in Durham, and was best known in the north to the profession as the organiser of the Friendly Societies' Convalescent Home; while the beneficent scheme itself, now an accomplished fact, was originated by Dr. William 